\title{
Penggunaan Skor Indeks Plasenta Akreta (IPA) sebagai Prediktor Manajemen Perioperatif Seksio Sesarea Pasien dengan Plasenta Previa Totalis Suspek Plasenta Akreta
}

\author{
Dadik Wahyu Wijaya ${ }^{1}$, Yusmein Uyun ${ }^{2}$, Sri Rahardjo² \\ ${ }^{1}$ Departemen/SMF Anestesiologi dan Terapi Intensif Fakultas Kedokteran USU-RSUP H. Adam Malik, Medan, \\ ${ }^{2}$ Departemen Anestesi dan Terapi Intensif Fakultas Kedokteran Kesehatan Masyarakat Keperawatan Universitas \\ Gadjah Mada-RSUP Dr. Sardjito, Daerah Istimewa Yogyakarta
}

\begin{abstract}
Abstrak
Plasenta akreta adalah kelainan perlekatan plasenta yang menyebabkan kondisi kehamilan menjadi serius sehingga membutuhkan perhatian khusus secara perioperatif. Kasus ini menggambarkan manajemen anestesi yang sesuai untuk seksio sesarea dan total abdominal histerektomi karena plasenta previa totalis dugaan akreta. Seorang wanita berusia 33 tahun dipersiapkan untuk menjalani seksio sesarea elektif dan histerektomi total akibat plasenta previa totalis dengan kecurigaan tinggi terhadap akreta berdasarkan Skor Indeks Plasenta Akreta (IPA). Skor IPA adalah nilai pada beberapa parameter sonografi yang digunakan untuk menilai probabilitas sejauh mana plasenta menginvasi dinding rahim. Pemeriksaan penunjang dilakukan oleh dokter kandungan untuk mengkonfirmasi diagnosis. Pada pasien ini dilakukan tindakan anestesi umum untuk prosedur operasinya. Kadar hemoglobin pasien sebelum operasi adalah 9,1 g/dl. Dengan total perdarahan selama operasi adalah $2000 \mathrm{~mL}$. Estimasi kehilangan darah yang ditolerir untuk pasien ini adalah $633 \mathrm{ml}$. Pasien mendapatkan transfusi 2 (dua) kantong darah Packed Red Cell (PRC) dan 1(satu) kantong darah Whole Blood (WB). Kadar hemoglobin setelah transfusi adalah 8,9 g / dL Pasien dipulangkan dari rumah sakit dalam kondisi stabil setelah dirawat selama 3 hari diruangan. Sebagai simpulan, evaluasi dan persiapan perioperatif dan kolaborasi multidisiplin adalah kunci keberhasilan manajemen pasien dengan plasenta previa suspek akreta.
\end{abstract}

Kata kunci: histerektomi, indeks plasenta akreta, perioperatif, plasenta akreta, plasenta previa, seksio sesarea

\section{The Use of Placenta Accreta Index (PAI) Score as Perioperative Management Predictor of Sectio Caesarean Patient with Total Placenta Previa Suspected Placenta Accreta}

\begin{abstract}
Placenta accreta is a serious pregnancy condition caused by disorder of placenta attachment that needs a special consideration perioperatively. This case was described the propriate anesthesia management for cesarean section and total abdominal hysterectomy due to total placenta previa suspected accreta. A 33 years old woman considered for elective cesarean section and hysterectomy due to total placenta previa with high suspicion of accreta according to Placenta Accreta Index (PAI) Score. PAI Score is the sum of total score some parameters of sonography used to predict the probability of placental invasion to uterine. Supportive examination was done by the obstetrician to confirm the diagnosis. She underwent general anesthesia for the surgery. Patient's hemoglobin level before surgery was $9.1 \mathrm{~g} / \mathrm{dL}$. With total bleeding during the surgery is $2000 \mathrm{~mL}$. The allowable blood loss for the patient is 633 $\mathrm{mL}$. Patient was transfused with 2 bags of packed red cell (PRC) and 1 bag of whole blood (WB). The hemoglobin level after transfusion was $8.9 \mathrm{~g} / \mathrm{dL}$ She was discharged from the hospital in stable condition after being treated for 3 days at normal ward. As conclusion, perioperative evaluation and preparations and multidiscipline collaboration are the key for successful management for patient with placenta previa/accreta
\end{abstract}

Key words: cesarean section, hysterectomy, placenta accreta, perioperative, placenta previa, placenta accreta index 


\section{Pendahuluan}

Plasenta akreta merupakan istilah umum yang digunakan untuk menggambarkan kondisi klinis ketika bagian dari plasenta, atau seluruh plasenta, menginvasi dinding rahim sehingga sulit terlepas. Ketika villi korialis menginvasi hanya miometrium, dikatakan plasenta inkreta; sedangkan plasenta perkreta menggambarkan invasi miometrium dan serosa, dan kadangkadang ke organ-organ yang berdekatan, seperti kandung kemih..$^{1-3}$ Secara klinis, plasenta akreta menjadi masalah saat persalinan ketika plasenta tidak sepenuhnya terpisah dari rahim dan diikuti oleh perdarahan obstetrik yang masif, menyebabkan DIC, histerektomi, repair pada cedera ureter, kandung kemih, usus, atau struktur neurovaskular, sindrom gangguan pernapasan dewasa, reaksi transfusi akut, ketidakseimbangan elektrolit, dan gagal ginjal.,5 Hilangnya darah rata-rata persalinan pada wanita dengan plasenta akreta adalah 3.000-5.000 ml. Sebanyak 90\% pasien dengan plasenta akreta membutuhkan transfusi darah, dan 40\% membutuhkan lebih dari 10 unit PRC. Kematian ibu dengan plasenta akreta dilaporkan setinggi 7\%. Kematian ibu dapat terjadi meskipun perencanaan yang optimal, manajemen transfusi, dan perawatan bedah. Studi kohort dari 39.244 wanita yang menjalani sesar, peneliti mengidentifikasi 186 ternyata dilakukan sesarean histerektomi atas indikasi yang paling sering adalah plasenta akreta $(38 \%))^{4,6}$

Plasenta akreta menyebabkan 7\%-10\% dari kasus kematian ibu di dunia. Plasenta perkreta adalah tipe yang jarang, jika tidak didiagnosis dini, dapat menyebabkan morbiditas berat maternal. Seksio sesarea sebelumnya dan operasi intrauterin merupakan faktor risiko yang paling umum untuk plasenta akreta maupun perkreta. Sebuah penelitian baru menunjukkan bahwa tingkat operasi caesar telah meningkat di AS dari 5,5\% pada tahun 1970 menjadi $32,8 \%$ pada tahun 2010. ${ }^{7}$ Jika tingkat operasi caesar terus meningkat pada tingkat saat ini, lebih dari $50 \%$ dari semua kelahiran di AS diperkirakan dilakukan dengan operasi caesar pada tahun 2020. Hal ini bisa mengakibatkan lebih dari 6000 kasus plasenta previa, 4500 kasus plasenta akreta, dan 130 kematian ibu. ${ }^{4,7,8}$ Penanganan pasien dengan plasenta akreta sebaiknya melibatkan dokter spesialis dari berbagai disiplin ilmu seperti: Ahli Obstetri dan Ginekologi, Anestesi, Bedah Digestif dan Urologi, Hematologi, dan Radiologi. Persiapan yang matang akan memberikan luaran yang baik, dianjurkan untuk persalinan seksio sesarea secara elektif dan kemungkinan akan dilakukan histerektomi, oleh karena itu informasi kepada pasien dan keluarga akan segala resiko yang mungkin dapat terjadi harus dijelaskan lengkap dan jelas sebelum penandatanganan informed concent. Persiapan pra-bedah harus dilakukan secara baik terhadap kebugaran dan mental pasien, alat pantau tanda vital yang adekuat dan kontinyu, obat emergensi persiapan darah-plasma-trombosit serta faktor pembekuan sesuai dengan protokol transfusi masif. Didunia saat ini dikembangkan teknik insersi-oklusi melalui kateter ke arteri Uterina maupun arteri Iliaka/Hipogastrika durante operasi setelah janin lahir untuk mencegah perdarahan yang massif.9-11

Indeks Plasenta Akreta (IPA) adalah nilai pada masing-masing parameter sonografi yang digunakan untuk menilai probabilitas sejauh mana plasenta menginvasi dinding rahim.(lihat Tabel 1 pada lampiran). ${ }^{3,5,12,13}$ Penilaian Skor Indeks Plasenta Akreta (IPA) pada pasien dengan plasenta previa kecurigaan akreta yang akan menjalani tindakan seksio sesaria dapat menjadi prediktor yang cukup akurat baik sensitivitas maupun spesifisitasnya terhadap kejadian suatu plasenta akreta. ${ }^{14-17}$ Hal ini tentunya dapat berpengaruh terhadap persiapan perioperatif yang akan dilakukan terhadap pasien, baik dari segi pilihan tindakan bedah, tindakan anestesi maupun persiapan keseluruhan penunjang operasi yang akan dilakukan. Disisi lain dengan adanya prediksi dari nilai skor tersebut, dapat mengurangi/ meminimalisir kebutuhan akan diagnostik tambahan seperti MRI, dan atau penyediaan darah/komponen darah yang berlebihan. ${ }^{2,5,17}$ Tehnik anestesi regional dengan spinal atau epidural (tanpa gangguan pembekuan darah) pada manajemen anestesi pada seksio sesarea dengan plasenta akreta yang sudah dipersiapkan dengan baik dapat menjadi pilihan, oleh krena dapat memberikan analgesia yang baik, relaksasi 
yang cukup baik, dengan durasi operasi yang panjang, pasien dalam keadaan sadar sehingga lebih mudah memantau tanda vital selama proses pembedahan. Apabila diperlukan oleh karena situasi selama pembedahan, dapat dilanjutkan dengan anestesia umum, namun perlu diingat bahwa kehamlan merupakan salah satu kriteria yang sulit intubasi (difficult intubation). ${ }^{10,11,17,18}$

\section{Kasus}

\section{Anamnesa}

Seorang wanita hamil G3P2A0 berusia 33 tahun dengan usia kehamilan 34-35 minggu, datang ke rumah sakit pada tanggal 9 Oktober 2018, dengan keluhan keluar darah dari kemaluan yang dialami sejak sehari sebelum masuk rumah sakit berupa bercak-bercak atau flek kemerahan. Riwayat keluar darah atau flek ini sudah dialami sejak usia kehamilan 8 bulan (32-34 minggu) dan memberat sejak sehari sebelum masuk rumah sakit. Riwayat berhubungan/campur suami-istri disangkal. Riwayat mules-mules dan keluar air banyak dari kemaluan disangkal. Riwayat trauma atau dipijat juga disangkal. Pasien selama ini berobat teratur ke poliklinik kandungan (antenatal care) dengan dokter spesialis kandungan sebanyak 4 kali di rumah sakit dan didiagnosa oleh dokter dengan kehamilan dengan plasenta previa totalis dan direncanakan untuk operasi elektif kebidanan. Pasien juga menyangkal memiliki penyakit lain sebelumnya ataupun mengkonsumsi obat-obatan lain selama kehamilan. Riwayat persalinan sebelumnya pasien melahirkan 2 kali dengan seksio sesarea di rumah sakit dengan spesialis kebidanan, cukup bulan dan keduanya anak laki-laki dan saat ini kondisi sehat berusia 7 tahun dan 3 tahun.

\section{Pemeriksaan Fisik}

Pasien dalam keadaan sadar baik dengan tekanan darah $120 / 80 \mathrm{mmHg}$, denyut nadi $80 \mathrm{x} /$ menit, frekuensi nafas $20 \mathrm{x} /$ menit dan tidak tampak tanda tanda anemis, ikterus, dyspnoe, sianosis dan edema. Pada pemeriksaan fisik jantung, paru-paru dalam batas normal dan abdomen membesar asimetris, teraba tinggi fundus uteri 4 jari dibawah prosesus xiphoideus (bpx), gerakan janin dirasakan pasien dan denyut jantung janin terukur $144 \mathrm{x} /$ menit regular, dengan estimasi berat janin 2400-2800 gram. Pada pemeriksaan dalam (inspekulo) tampak ditemukan darah di fornik posterior dan bila dibersihkan kesan tidak mengalir aktif dari OUE, tampak gambaran lividae, tidak ditemukan ada kuputihan (Fluor Albus) dan massa.

\section{Pemeriksaan Laboratorium}

Didapatkan anemia ringan ( $\mathrm{Hb}$ 9,1 gr/dL), leukosit 11.170/mm3 dan trombosit 227.000/ mm3 dengan faal hemostatik dalam batas normal. Pemeriksaan fungsi ginjal, elentrolit dan gula darah juga dalam batas normal.

Pada pasien ini dilakukan pemeriksaan penunjang ultrasonografi (USG) TAS (Trans Abdominal Sonography) dengan hasil pada gambar 1 .

- Janin tunggal, Presentasi Kepala, Anak hidup

- $\quad$ FM (+). FHR (+)

- BPD: $8,43 \mathrm{~cm}$
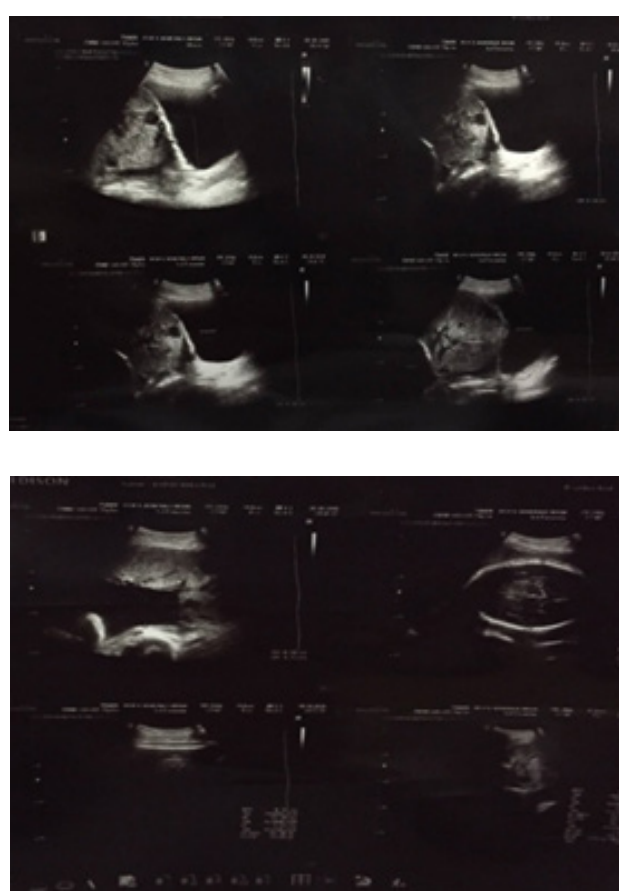

- $\mathrm{AC}: 31,3 \mathrm{~cm}$

- HC: $31,14 \mathrm{~cm}$

- FL: $6,51 \mathrm{~cm}$

- MVP: $4,32 \mathrm{~cm}$

- EFW: $2597 \mathrm{gr}$

- Plasenta menutupi seluruh OUI

- Myometrial thickness 1,4 mm 
- $\quad$ Bridging vessel $(+)$

- Lacunae $(+)$

Kesimpulan:

Plasenta previa totalis suspek akreta + KDR (3435) minggu + Presentasi Kepala + Anak Hidup

\section{Pengelolaan Anestesi}

Pasien dilakukan tindakan anestesi umum dengan intubasi (GA) dimana sehari sebelumnya terlebih dahulu dilakukan persiapan preoperatif berupa edukasi atau penjelasan tentang resiko anestesi dan pembedahan (informed consent), puasa 6-8 jam preoperatif dan pemasangan infus cairan Ringer Laktat dan memastikan infus lancar dengan kaliber yang cukup (minimal No 18G). Untuk mengantisipasi perdarahan yang timbul dipersiapkan penyediaan darah 2 kantong Darah Lengkap (WB) dan 2 kantong Sel Darah Merah (PRC). Sebelum jadwal operasi ditetapkan, dipastikan Tim Akreta? Rumah Sakit yang terdiri dari Tim Multidisiplin dari Anestesi, Kebidanan Feto-Maternal, Kebidanan Onkologi, Bedah Digestif dan Bedah Urologi mengetahui jadwal yang sudah disepakati untuk tindakan operasi seksio sesaria elektif pasien ini. Prosedur operasi berjalan lancar selama 3 jam mulai pukul 09.00 hingga pukul 12.00 WIB, dan dilakukan sesuai protokol dengan kontrol perdarahan yang baik. Dilakukan tindakan operasi seksio sesaria
Tabel 1. Nilai masing-masing parameter yang digunakan untuk penilaian Skor Indeks Plasenta Akreta (IPA)

\begin{tabular}{ll}
\hline Parameter & Nilai \\
\hline Operasi sesar $\geq 2$ & 3,0 \\
Lakuna & \\
Grade 3 & 3,5 \\
Grade 2 & 1,5
\end{tabular}

Letak sagital terkecil dari ketebalan miometrium

$\begin{array}{ll}<1 \mathrm{~mm} & 1,0 \\ 1-3 \mathrm{~mm} & 0,5 \\ 3-5 \mathrm{~mm} & 0,25 \\ \text { Plasenta previa anterior } & 1,0 \\ \text { bridging vessel } & 0,5\end{array}$

Keterangan: Skor IPA = hasil jumlah nilai parameter yang ditemukan.

Jika parameter tidak ada, maka nilainya adalah 0. (Rac. Placenta Accreta Index Am J Obstet Gynecol 2015) $)^{1,6,9,10,11}$

dengan midline incision dan lahir bayi laki laki sehat, berat 2450 gram, panjang badan $47 \mathrm{~cm}$ dan Apgar Score 8/9 dilanjutkan dengan prosedur total histerektomi (TAH) oleh tim obstetri. Hemodinamik pasien durante operasi relatif stabil dengan perdarahan tercatatat $\pm 2000 \mathrm{ml}$, pasien mendapatkan substitusi cairan $\mathrm{RL} / \mathrm{NaCl} 0,9 \%$ $2000 \mathrm{ml}$ dan transfusi 2 bag PRC dan 1 bag WB, dengan produksi urin $600 \mathrm{ml}$ selama operasi.

Tabel 2. Monitoring Pasien Durante Operasi

\begin{tabular}{|c|c|c|c|c|}
\hline Waktu & $\begin{array}{c}\text { TD (mmHg) - Nadi (x/ } \\
\text { mnt) }\end{array}$ & Urine (cc) & $\begin{array}{c}\text { Perdarahan } \\
\text { (cc) }\end{array}$ & $\begin{array}{c}\text { Cairan/Darah } \\
\text { yang masuk (cc) }\end{array}$ \\
\hline $\begin{array}{l}08.45 \\
\text { (mulai operasi) }\end{array}$ & $125 / 88-86$ & 0 & 0 & RL fls1+ \\
\hline 09.00 & $104 / 92-96$ & $100+$ & 0 & RL fls $2+$ \\
\hline 09.30 & $98 / 56-104$ & $150+$ & $200+$ & $\mathrm{NaCl} 0,9 \%$ fls $1+$ \\
\hline 10.00 & $94 / 50-112$ & $70+$ & $500+$ & WB bag1+ \\
\hline 10.30 & $108 / 52-88$ & $80+$ & $700+$ & PRC bag1+ \\
\hline 11.00 & $115 / 65-84$ & $50+$ & $500+$ & PRC bag2 + \\
\hline 11.30 & $122 / 76-82$ & $150+$ & $100+$ & RL fls $3+$ \\
\hline $\begin{array}{l}12.00 \\
\text { (operasi selesai) }\end{array}$ & $118 / 82-88$ & $\begin{array}{l}600 \mathrm{cc} \\
\text { (Total Urine) }\end{array}$ & $\begin{array}{l}2000 \mathrm{cc} \\
\text { (Total) }\end{array}$ & $\begin{array}{l}\text { RL } 1500 \mathrm{cc} \\
\mathrm{NaCl} 0,9 \% 500 \mathrm{cc} \\
\text { WB } 250 \mathrm{cc} \\
\text { PRC } 350 \mathrm{cc} \\
\text { (Total Darah } \\
\text { /Transfusi) }\end{array}$ \\
\hline
\end{tabular}


Penggunaan Skor Indeks Plasenta Akreta (IPA) sebagai Prediktor Manajemen Perioperatif Seksio Sesarea Pasien dengan Plasenta Previa

Totalis Suspek Plasenta Akreta

Tabel 3. Sensitivitas, Spesifisitas, Positive and Negative Predictive Value Berdasarkan Jumlah Skor IPA

\begin{tabular}{|c|c|c|c|c|c|c|}
\hline & & Probability & Sensitivity & Specificity & $P P V$ & $N P V$ \\
\hline PAI & $\mathrm{n}$ & $\begin{array}{c}\text { Invasion, } \% \\
(95 \% \mathrm{Cl})\end{array}$ & $(95 \% \mathrm{Cl})$ & $(95 \% \mathrm{Cl})$ & $(95 \% \mathrm{Cl})$ & $(95 \% \mathrm{Cl})$ \\
\hline$>0$ & 1 & $5(1-15)$ & $100(88-100)$ & $19(10-31)$ & $38(27-49)$ & $38(27-49)$ \\
\hline$>1$ & 1 & $10(4-22)$ & $97(82-100)$ & $47(34-61)$ & $47(34-61)$ & $97(82-100)$ \\
\hline$>2$ & 2 & $19(10-32)$ & $93(77-99)$ & $58(44-70)$ & $52(38-66)$ & $94(81-99)$ \\
\hline$>3$ & 4 & $33(22-47)$ & $86(68-96)$ & $68(54-79)$ & $57(41-72)$ & $91(78-97)$ \\
\hline$>4$ & 6 & $51(36-66)$ & $72(53-87)$ & $85(73-93)$ & $70(51-85)$ & $86(75-94)$ \\
\hline$>5$ & 6 & $69(50-83)$ & $52(33-71)$ & $92(81-97)$ & $75(51-91)$ & $79(68-88)$ \\
\hline$>6$ & 2 & $83(63-93)$ & $31(15-51)$ & $100(94-100)$ & $100(66-100)$ & $75(64-84)$ \\
\hline$>7$ & 2 & $91(73-97)$ & $24(10-44)$ & $100(94-100)$ & $100(59-100)$ & $73(62-82)$ \\
\hline$>8$ & 5 & $96(81-99)$ & $17(6-36)$ & $100(94-100)$ & $100(48-100)$ & $71(60-81)$ \\
\hline
\end{tabular}

$\mathrm{Cl}$, confidence interval; NPV, negative predictive value; PAI, placenta accreta index; PPV, positive predictive value. (Rac. Placenta Accreta Index Am J Obstet Gynecol 2015) 1,6,9,10,11

Pengelolaan Pascabedah

Operasi selesai dengan keadaan umum dan hemodinamik pasien stabil kemudian dipindahkan ke ruangan pemulihan, dilanjutkan transfusi 1 kantong WB lagi. Pemberian terapi pasca bedah dan rencana pemantauan tanda tanda vital, perdarahan, dan pemeriksaaan darah rutin ulangan 6 jam paska bedah dan transfusi. Hasil darah rutin paska operasi didapati $\mathrm{Hb} / \mathrm{Ht} /$ Leukosit/Trombosit: 8,9/30,9/ 22.430/ 163.000. Pasien dirawat selama 3 hari setelah operasi dan keluar rumah sakit dengan keadaan umum stabil dan luka operasi kesan kering, dengan anjuran kontrol ke poliklinik. Pada saat menjelang akhir

\begin{tabular}{ll}
\hline Parameter & Nilai \\
\hline Operasi sesar $>2 \mathrm{x}$ & 3,0 \\
$\quad$ Lakuna & \\
$\quad$ Grade 3 & 3,5 \\
Letak sagital terkecil dari ketebalan & 0,5 \\
myometrium & \\
1-3 mm & \\
Plasenta previa anterior & 0,1 \\
Bridging vessel & 0,5 \\
Total & 8,5 \\
\hline
\end{tabular}

operasi tim operator mengambil sedikit jaringan uterus yang berada di lokasi perlengketan plasenta previa/akreta, untuk selanjutnya dikirim ke laboratorium Patologi Anatomi untuk memastikan diagnosa yang dibuat. ${ }^{14,15}$

\section{Hasil Pemeriksaan Patologi Anatomi \\ Makroskopik:}

Diterima jaringan uterus dengan ukuran: $19 \mathrm{x}$ $11 \times 9 \mathrm{~cm}$. Pada pembelahan dijumpai plasenta di dekat serviks dan lengket ke dinding uterus, konsistensi kenyal berwarna coklat kemerahan. Tali pusat panjang $7 \mathrm{~cm}$ warna putih transparan. Mikroskopik:

Sediaan jaringan plasenta terdiri dari villi choriales yang tersusun sel-sel dengan inti eksentrik, sitoplasma jernih dan tertarik kepinggir yang dilapisi oleh sel-sel trophoblast. Tampak villi sudah menginvasi hingga lapisan miometrium. Stroma terdiri dari sel-sel bulat basofilik hingga proliferasi pembuluh darah disertai perdarahan intertisial. Tampak juga infiltrasi sedang sel-sel radang limfosit. Kesimpulan: Plasenta Inkreta

\section{Pembahasan}

Telah dilaporkan sebuah kasus plasenta previa totalis dengan akreta + previous seksio sesarea $2 \mathrm{x}$ + multigravida + kehamilan dalam rahim (34-35 minggu) + presentasi kepala + anak hidup, dengan keluhan utama keluar darah dari kemaluan. Ini merupakan suatu gejala yang objektif yang sering dialami oleh penderita plasenta previa. Pada kasus ini dilakukan seksio sesaria dan total abdominal 
histerektomi. Pada saat preoperatif didapatkan Skor Plasenta Akreta Indeks sebagai berikut: Dari tabel sensitivitas dan spesifisitas AJOG2015 (lihat tabel 2 lampiran) dapat diprediksi bahwa dengan skor IPA $=8,5$ pada pasien ini didapat persentase kemungkinan plasenta akreta adalah 96\%.5,6,14-16 Dari penjelasan tersebut dapat di simpulkan bahwa pasien memiliki sangkaan plasenta akreta yang tinggi, walaupun pada literatur dibutuhkan pemeriksaan MRI untuk menentukan sejauh mana regio invasi plasenta, agar memudahkan penentuan tindakan konservatif atau definitif yaitu total histerektomi, namun pada kasus ini tidak dilakukan karena tidak efisien dan rutin dilakukan di Rumah Sakit ini. Pada pasien ini langsung direncanakan seksio sesaria dilanjutkan histerektomi total (TAH) setelah mempertimbangkan total skor IPA pasien. Pasien dengan jalan napas bebas dengan hemodinamik stabil dan tidak ada penyakit penyerta. Riwayat pemakaian obat terdahulu tidak ada dan tidak ada riwayat alergi obatobatan. Dari hasil laboratorium diketahui dengan Hb: 9,1, Leukosit: 11.170, Hematokrit: 29, Trombosit: 227.000, Ureum/Creatinin: 11/0,48, KGD ad random: 91, Natrium/Kalium/ Chlorida: 135/3.7/106, HbsAg: Non Reactive, HIV: Non Reactive. TT: 14.6 (C : 20.3s.), APTT: 27.2 (C; 34.9s.), PT: 12.9 (C: 14.40s.), INR: 0.88 (C: 0,8$1,3)$.

Pasien direncanakan puasa 6-8 jam sebelum operasi dengan pemasangan IV kateter minimal nomor 18 dan dipastikan aliran lancar. Untuk persiapan darah operasi disediakan 2 kantong darah PRC (350 cc) dan 2 kantong darah WB (500 cc) dengan perkiraan volume darah pada pasien dengan berat badan $65 \mathrm{~kg}$ yaitu 4.225 cc. Diberikan injeksi antibiotik ceftriaxone 2 gram/iv sebagai profilaksis. Tindakan operasi dilakukan dengan prosedur Anestesi Umum (GAETT), dan prosedur operasi dilakukan sesuai protokol dengan kontrol perdarahan yang baik. Hemodinamik pasien durante operasi diketahui stabil dengan pemberian cairan dan transfusi 2 kantong darah PRC dan 1 kantong darah WB. Produksi urin cukup sekitar $0,5 \mathrm{cc}-1 \mathrm{cc} / \mathrm{kgbb} / \mathrm{jam}$ dengan perdarahan tercatat $\pm 2000 \mathrm{cc}$.
Pilihan menggunakan prosedur Anestesi Umum (GA-ETT) berdasarkan riwayat tatalaksana pasien sebelumnya di rumah sakit ini, dimana pada kasus sejenis tanpa persiapan yang cukup, baik skoring kasus (IPA Skor), kerjasama tim yang solid dan antisipasi kemungkinan terjadinya perdarahan masif, terjadi ketidak pastian lama prosedur operasi dan anestesi yang dilakukan, bahkan beberapa kali terjadi perdarahan masif yang tidak terkontrol dan berakibat kepada mortalitas pasien. ${ }^{3,5,6,10}$ Perkiraan kehilangan darah pada pasien apabila volume darah yang diperkirakan adalah $65 \mathrm{ml} / \mathrm{kg}$ dari Berat Badan $(65 \mathrm{~kg})=4.225 \mathrm{ml}$, yaitu: ${ }^{10,11}$

Dengan perhitungan estimated red blood cell volume (RBCV) dengan hematokrit preoperasi (RBCVpreop) $29 \%=4225 \mathrm{ml} \times 29 \%=1.225$ $\mathrm{ml}$. Dengan menghitung RBCV pada hematokrit $24 \%$ di asumsikan bahwa jika penurunan Hematokrit didapati 24\% atau kurang diindikasi kan untuk transfusi darah. Dengan perhitungan: $\mathrm{RBCV} 24 \%=4225 \mathrm{ml} \times 24 \%=1.014 \mathrm{ml} \mathrm{Jadi}$ Sel darah merah yang hilang (RBCVlost) yang dapat membuat Hematokrit turun menajadi $24 \%$ adalah $1.225 \mathrm{ml}-1.014 \mathrm{ml}=211 \mathrm{ml}$. Kesimpulannya jumlah kehilangan darah yang dapat di tolerir adalah (RBCVlost) x $3=633 \mathrm{ml}$.

Jika disesuaikan dengan pasien diatas yang kehilangan darah sebanyak $2.000 \mathrm{ml}$ (3 kali lipat dari kehilangan darah yang di tolerir) sebaiknya di berikan 3 kantong produk darah agar hematokrit diatas $24 \%$ atau kadar hemoglobin diatas $8 \mathrm{mg} / \mathrm{dl}$. Operasi selesai dengan keadaan umum, hemodinamik pasien stabil dan di pindahkan ke ruangan pasca bedah dan dilanjutkan transfusi 1 kantong WB lagi yang tersedia. Pemberian terapi pasca bedah dan rencana pemantauan vital sign, perdarahan, dan pemeriksaaan darah rutin 6 jam post operasi/ transfusi. Hasil darah rutin post operasi didapati Hb/Ht/Leukosit/trombosit: 8,9/ 30,9/ 22.430/ 163.000. Pasien dirawat selama 3 hari setelah operasi dan dipulangkan untuk berobat jalan dan kontrol ke poliklinik pada tanggal 15 Oktober 2018 (seminggu post operasi) dengan keadaan umum stabil dan luka operasi kesan kering. 


\section{Simpulan}

Penggunaan Skor Indeks Plasenta Akreta (IPA) sebagai prediktor disertai dengan persiapan dan evaluasi preoperatif yang baik serta keterlibatan multidisiplin yang solid dan terpadu adalah kunci suksesnya manajemen perioperatif pasien seksio sesaria dengan plasenta previa yang dicurigai plasenta akreta.

\section{Daftar Pustaka}

1. Gabbe SG, Niebyl JR, Simpson JL, Landon MB, Galan HL, Jauniaux ERM et al. Obstetrics: Normal and Problem Pregnancies, 7th Ed. 2017. Philadelpia, Elsevier.

2. Petersen OMF, Debra SH, Vijay VJ. Handbook of Placental Pathology, 2nd ed. 2006. Boca Raton, Taylor \& Francis.

3. Sivasankar C. Perioperative management of undiagnosed placenta percreta: case report and management strategies. Int $\mathrm{J}$ Womens Health. 2012;4:451-54.

4. Silver R. Placenta Accreta Syndrome. 2017. Boca Raton, Taylor \& Francis.

5. Hudon L, Belfort MA, Broome DR. Diagnosis and management of placenta percreta: a review. Obstet Gynecol Surv. 1998;53(8):509-17.

6. Committee on Obstetric Practice. Committee opinion no. 529: placenta accreta. Obstet Gynecol. 2012;120(1):207-11.

7. Cunningham FG, Leveno KJ, Bloom SL, Dashe JS, Hoffman BL, Casey BM et al. Williams Obstetrics, 24th Ed. New York, McGraw Hill, 2014; 36-40.

8. Rac MW, Dashe JS, Wells CE, Moschos E, McIntire DD, Twickler DM. Ultrasound predictors of placental invasion: the Placenta Accreta Index. Am J Obstet Gynecol. 2015;212(3):343.
9. Jauniaux E, Jurkovic D. Placenta accreta: pathogenesis of a 20th century iatrogenic uterine disease. Placenta. 2012;33(4):244-51.

10. Binici $O$, Büyükfirat E. Anesthesia for Cesarean Section in Parturients with Abnormal Placentation: A Retrospective Study. Cureus. 2019;11(6).

11. Orbach-Zinger S, Weiniger CF, Aviram A, et al. Anesthesia management of complete versus incomplete placenta previa: a retrospective cohort study. J Matern Fetal Neonatal Med. 2018;31(9):117176.

12. Berkley EM, Abuhamad AZ. Prenatal diagnosis of placenta accreta: is sonography all we need?. J Ultrasound Med. 2013;32(8):1345-50.

13. 13. Fauzan, Wulan AI, Tiarma UP, Febriansyah D, Bintari $P$, et al. USG Untuk Deteksi Plasenta Akreta. CDK. 2017;4(8):586-90.

14. Abdulsalam RAH, Mohammed EDA, Amr MEH, \& Marwa L. 2017. Histological and Histopathological Study of Lower Uterine Segment After Previous Cesarean Section and Placenta Accreta. International Journal of Basic and Applied Science. 6(4):90-101.

15. Jauniaux E, Chantraine F, Silver RM, Langhoff-Roos J; FIGO Placenta Accreta Diagnosis and Management Expert Consensus Panel. FIGO consensus guidelines on placenta accreta spectrum disorders: Epidemiology. Int $\mathrm{J}$ Gynaecol Obstet. 2018;140(3):265-73.

16. Jauniaux E, Collins S, Burton GJ. Placenta accreta spectrum: pathophysiology and evidence-based anatomy for prenatal ultrasound imaging. Am J Obstet Gynecol. 2018;218(1):75-87.

17. Publications Committee, Society for Maternal-Fetal Medicine, Belfort MA. Placenta accreta. Am J Obstet Gynecol. 
2010;203(5):430-39.

18. Paech MJ, Scott KL, Clavisi O, Chua S, McDonnell N; ANZCA Trials Group. A prospective study of awareness and recall associated with general anaesthesia for caesarean section. Int $\mathrm{J}$ Obstet Anesth. 2008;17(4):298-303. 